\title{
Recovering Rural Economies: Two cases in Taiwan
}

\author{
Liang-Chih Chen, Shenglin Elijah Chang \\ Graduate Institute of Building and Planning, \\ National Taiwan University, Taiwan \\ liangchih@ntu.edu.tw
}

\begin{abstract}
This paper concerns how rural villages recover their declining local economies based on two case studies in Taiwan, namely, the liquor industry in Sinyi, Nantou, and eco-friendly tea industry in Pinglin, New Taipei. Specifically, we study the processes through which rural villages managed to build new or transform old agricultural activities under different sectoral and local contexts, and, particularly, examine the roles of institutional actors, such as farmers associations and universities, in facilitating the recovery processes.
\end{abstract}

Keywords: rural economy, farmers association, university, Taiwan

eISSN: 2398-4279 @ 2017. The Authors. Published for AMER ABRA by e-International Publishing House, Ltd., UK. This is an open access article under the CC BY-NC-ND license (http://creativecommons.org/licenses/by-ncnd/4.0/). Peer-review under responsibility of AMER (Association of Malaysian Environment-Behaviour Researchers), ABRA (Association of Behavioural Researchers on Asians) and cE-Bs (Centre for EnvironmentBehaviour Studies), Faculty of Architecture, Planning \& Surveying, UniversitiTeknologi MARA, Malaysia.

https://doi.org/10.21834/ajqol.v2i7.61 


\subsection{Introduction}

Agriculture has long been perceived as a less significant sector than its industrial and service counterparts in supporting local, regional and national economies, leading to serious declines in rural development in almost every country around the world (Terluin 2003, Shucksmith 2010). This declines of the agricultural industry has not only adversely affected the economic welfare of people working in this sector but, more generally, is also seen as a threat to the quality of human life in the future, as evidenced by the emerging global fear of food scarcity and of insufficient natural environments necessary to support and sustain human activities. How to save and strength rural economies now, therefore, have become critical problems that scholars and policy-makers have to find ways to deal with (Chang \& Huang 2013, Murdoch 2000). In response to such concerns, by using two cases in Taiwan as the examples, namely, the liquor industry in Sinyi Township, Nantou County, and the eco-friendly tea industry in Pinglin Township, New Taipei City, this paper aims to understand how rural villages could recover their declined local economies with a specific focus on the roles of institutional actors, such as farmers associations and universities, in facilitating the processes.

This study relies mainly on qualitative data collected from 38 cases of in-depth interviews conducted by the authors with participants critically involved in the industrybuilding projects, along with participatory observation by the authors and their research teams between 2011 and 2014. To analyze the processes, we adopt mainly the network perspectives (Murdoch 2000), such as actor-network theory (Law 1992, Murdoch 1998), that emphasize investigation and discussion of interactions among heterogeneous networked actors, both human and non-human, to gain a better understanding of the dynamics and outcomes of rural development. In the following sections, we then will present our findings while the final section concludes.

\subsection{Sinyi's local liquors: Building a new rural industry}

Located in Nantou County in central Taiwan, Sinyi Township is Taiwan's second largest township covering an area of 1422 square kilometers and has been renowned as the plum county that has been promoting the sales of plum and plum related products. However, on September 21, 2000, central Taiwan was hit by a major earthquake. Sinyi was near the epicenter, and the earthquake caused extensive damage to local landscapes and infrastructure, severely hurting Sinyi's plum industry. As a rural area with a low level of industrial diversity and limited local resources, Sinyi faced huge challenges in rebuilding its economy. In addition to making efforts to recover its agricultural activities to pre-earthquake levels, the Sinyi Township Farmers Association (STFA) took the opportunity to establish a new industrial sector on liquor production, the emergence of which has consequently contributed significantly to the resurgence of Sinyi's vitality. In the following parts, we discuss why and how Sinyi managed to enter the liquor-making business and the actors 
involved in such an industry-building project, as well as these actors' interactions during the process.

\subsection{The initiation of liquor-making project}

To drive the economic recovery of rural villages in the earthquake area, agro-related sustainable tourism combined with regional identities has been a critical option (Soh and Omar 2012, Sani \& Mahasti 2013). In 2001, the Taiwanese government devised an industrial development plan in which liquor-making, was selected as a strategic sector to be promoted in rural villages. To facilitate the emergence of the liquor-making sector in the earthquake area, the Taiwanese government started by subsidizing some local agricultural organizations, such as farmer associations or other farmers' cooperatives. In the case of Sinyi, envisioning that promoting rural liquor-making might be able to restore or potentially upgrade Sinyi's damaged plum industry, and to create additional opportunities for tourism development, the STFA answered the government's call and decided to invest in the establishment of a winery, eventually becoming one of the nine organizations participating in this government-initiated project. In 2002, the STFA Winery obtained its liquor-making license, which was the first license issued by the Taiwanese government to the private wineries.

\subsection{Resources mobilized}

To foster the burgeon of the rural liquor-making sector, Taiwanese government initiated a series of strategies to facilitate the capability-building of rural wineries. It first invited scholars and researchers with expertise in liquor making to form an R\&D taskforce to screen suitable local materials and procedures for making liquors in Taiwan. In the meantime, some of these scholars were also asked to help train liquor-making manpower through government-funded training programs. In addition to government's top-down financial and technological assistance, the bottom-up efforts by the STFA in terms of mobilizing its internal and external resources to support the project were particularly crucial. Given the fact that the public subsidies were only sufficient to partially finance equipment acquisition, the STFA had to bear most of the winery's construction costs, totaling over NT\$20 million. Moreover, the manpower of STFA was also aggressively mobilized. For instance, the staffs in its existing plum processing plant who were already equipped with a certain level of food processing experience were dispatched to attend government's training programs so as to learn liquor-making related techniques. Other STFA divisions were also involved in the project, with the Promotion Division assisting local farmers to produce quality materials for liquor-making, the Marketing and Logistic Division handling logistics, the Accounting Division managing the winery's finances, and the Recreational Tourism Division redesigning local tourism programs toward liquor-making related activities. As a result of the above-mentioned aggressive mobilization of STFA's resources, the winery was able to commence operations in 2003 , only one year after the initiation of this project. 


\subsection{Dynamics of the development of local liquors}

In the project of developing liquor-making industry in rural villages, one of the most challenging tasks has been to build up technological capability required for making commercialized liquors. In the case of Sinyi, local liquor production was active as early as the Japanese colonial period. Unlike rural wineries in other regions had relatively limited prior experiences in making liquors, the STFA was able to leverage the community's collective expertise in liquor-making. However, given the embedded local knowledge in making plum liquors involved mostly informal skills and experiences that were insufficient for reliable industrial production, the STFA sought assistance from government agencies, along with technological input from scholars in local universities to address such issues.

On the one hand, in the case of government, the provision of subsidies enabled the STFA Winery to acquire critical technologies such as advanced fermented and distilling equipment. Publicly-funded training programs then allowed Sinyi's amateur liquor-makers to learn basic concepts and scientific knowledge required for the mass-production and R\&D of liquor products. Also, the regular project meetings held by relevant government agencies provided another important platform through which the STFA Winery was able to interact with other rural wineries involved in this project to discuss issues and exchange ideas. The taskforce organized by the authority to supervise the project implementation further helped to provide critical suggestions about winery operation through on-site visits.

On the other hand, to ascertain the required specialized liquor-making technology and local knowledge, STFA Winery staff worked closely with scholars from local universities. Specifically, the STFA invited professors with backgrounds in fields related to liquor-making from the nearby university to be its consultants and help the winery to optimize the process of liquor making. For instance, Sinyi's farmers had long been using one certain kind of yeast in the fermentation of plum liquor without knowing that this yeast was only adequate for making grain liquor and might be a major cause of considerable variability in the flavor of the resulting liquor. Consultation with external researchers helped identify this problem, and winery staff began experimenting with various kinds of yeast, eventually identifying yeasts suitable for their fermented and distilled plum liquors. In addition to know-how in fermentation, the STFA winery's technologies in areas such as flavor analysis or quality stabilization, etc., were also greatly improved as a result of its intensive cooperation with local scholars, leading to the successful transformation of Sinyi's existing amateur liquors of questionable and unreliable quality to truly commercial and marketable products.

\subsection{Current status and prospects of the Sinyi Winery}

Since its establishment, the STFA Winery has been the chief driver of Sinyi's liquor-making industry. By relying on local materials, the local liquor sector helps to sustain the area's plum industry and, more importantly, to stimulate the overall rural economy of this village following the earthquake. Moreover, equipped with advanced food processing and R\&D capabilities that it obtained and accumulated during the learning process for liquor-making, the STFA is now able to introduce a variety of plum related products, including high-end 
products such as plum essence. The winery's consistent efforts to improve quality have met with international recognition, earning top honors in some of the world's most reputable liquor competitions, including the Germany's International Spirits Award, Belgium's Concours Mondial de Bruxelles, and France's Vinalies Internationales. The STFA winery's renowned liquors further made it the most popular tourist spot in Sinyi, consequently helping to trigger the growth of local tourism industry.

\subsection{Pinglin's eco-friendly tea: Transforming an existing rural industry}

Located in the northeast corner of Taiwan, Pinglin Township convers an area of 170 square kilometers on the outskirts of Taipei city. It is the site of Feitsui Reservoir, the primary source of drinking water for six million people living in the Taipei basin. Restrictions on land use within the water protection zone leave tea farming and small industry as the only means for residents to make the living. However, for the past two decades, the local market for tea products has been saturated by cheap tea imported from China, dramatically damaging the viability of local teas. Also, the completion of a highway tunnel has routed potential tourist traffic away from Pinglin. Due to these factors, local economic performance sharply declined.

To address the serious economic issues presented in Pinglin, students and faculty from a nearby academic institution, the Graduate Institute of Building and Planning at National Taiwan University (BP-NTU), initiated the Blue Magpie Tea project that targets three-fold transformations of Pinglin's rural development (Chang 2013):

(1) To initiate a moral economy and a fair-trade business that help re-establish farmers' ways of life and re-gain farmers' dignity; (2) To experiment with environmentally-friendly satoyama tea farming systems in an attempt to rehabilitate Pinglin's tea plantations that had been damaged by conventional farming methods and which had polluted the water quality in the Feitsui Reservoir; and

(3) To call for the new tea generation, i.e. young generations in local, national and global scales, to join healthy tea culture and drink eco-friendly tea that might consequently encourage more young talents to come to Pinglin.

\subsection{The initiation of the Blue Magpie Tea Social Enterprise}

The Blue Magpie Tea idea originally came from the successful rehabilitation of Oriental storks through the introduction of wildlife-friendly rice farming techniques in Toyooka, Japan. During the summer of 2012, BP-NTU set up a Study Abroad Studio (SAS) course and visited Toyooka to investigate local development experiences, and experts from Toyooka later visited Pinglin to consult on the development of Blue Magpie Tea. With the advice from Toyooka experts, the Blue Magpie Tea has been positioned as a high-end product that could be sold at a high price, given the fact that the price could provide the Pinglin tea farmers with the dignity and establish a fair trade relationship, as in the words of 
the leader of Japanese experts, "Pricing is the key. Local farmers have to be treated fairly. Only with a price high can farmers produce high quality, environmental friendly tea."

Based on above ideas, BP-NTU calculated input costs for participating farmers and established a purchase price. To protect tea farmers' living and ensure the stability of the Blue Magpie tea business, in early 2013 BP-NTU then applied for government funding and founded the New Ruralism Social Enterprise (henceforth, the New Ruralism SE) that serves not only as the operation entity, but also promotes eco-friendly lifestyles and food systems (Asmuni, Khalili, and Zain 2012, Yusof and Rahman 2013). The Blue Magpie Tea brand introduced by the New Ruralism SE was accordingly given birth.

\subsection{Resources mobilized}

To initiate the Blue Magpie Tea project, resources from both the private sector and the university were mobilized. In the process, the BP-NTUs SAS has played a critical role in recruiting students to help run the new business, earning course credits while volunteering in the enterprise. These students also helped market Blue Magpie tea as a local, ecofriendly drink to independent cafés in major cities around Taiwan. They also developed customized holiday season gift packages for companies and institutions and promoted ecotours for tourists. To develop closer relationships with local families which placed great value on the education of their children, they further created a series of after-school youth tutoring programs in which the children of participating tea farmers received weekly tutoring in their school coursework from NTU students.

\subsection{The dynamics, current status and prospects of Blue Magpie Tea}

Currently, the Blue Magpie Tea project is supported in various ways by different institutes at NTU. In particularly, seven NTU professors in the Climate Change and Sustainable Development Program organized an interdisciplinary capstone course in which enrolled students would visit Pinglin every week, and spent a total of 24 hours there learning teamaking practices during the spring tea harvest. At the end of the course, groups of students were asked to propose comprehensive solutions to help tea farmers in Pinglin adjust to the impact of climate change. Also, faculty and students from NTU's Forestry Department started to map environmentally-friendly tea plantations using Public Participatory GIS methods.

The New Ruralism SE has since continued to send additional delegations to Japan and Korea to learn about rural development practices along with the management of social enterprises. It also organized some events such as eco-friendly tea tours, tea ceremonies, and lectures in domestic and global occasions. These efforts, to promote an eco-friendly tea movement, have been widely reported in Taiwan's broadcast media coverage without the need for celebrity endorsements (Muda and Putit 2011), and Blue Magpie Tea has emerged as an important brand for younger, health-conscious tea drinkers in Taiwan. 


\subsection{Concluding Remarks}

This paper focuses on means by which rural areas can develop viable local agro-food sectors. More specifically, we particularly study the key actors involved in the processes through which rural villages managed to recover from declining economies under different sectoral and local contexts. In the two economically-challenged rural townships of Sinyi and Pinglin, the successful emergence of new rural sectors is shown to benefit from the development and exploitation of local resources, including natural endowments, local expertise, and human capital. Moreover, this paper particularly points out the key roles played by institutional actors in driving the process. In Sinyi, development was championed by local farmers association while university faculty and students promoted efforts in Pinglin both influencing the direction and process of rural development (see Table 1). As demonstrated in this paper, these institutional actors not only acted as initiators but also actively mobilized intra- and extra-organizational resources and built networks to connect various players in nurturing the development of technological or marketing capabilities required to promote these industry-building projects.

Table 1. The comparison of Sinyi's and Pinglin's industry-building projects

\begin{tabular}{|c|c|c|}
\hline & Sinyi & Pinglin \\
\hline Main tasks & $\begin{array}{l}\text { - stimulating declining rural economy } \\
\text { through creating a new industry: The } \\
\text { local liquor }\end{array}$ & $\begin{array}{l}\text { - stimulating declining rural economy } \\
\text { through transforming existing industry: } \\
\text { The eco-friendly tea }\end{array}$ \\
\hline Strategies & $\begin{array}{l}\text { - establishing rural winery } \\
\text { - developing local liquors } \\
\text { - promoting plum tourism }\end{array}$ & $\begin{array}{l}\text { - promoting tea cultural tours } \\
\text { - public lectures } \\
\text { - tea ceremonies } \\
\text { - tea farmers' children tutoring }\end{array}$ \\
\hline \multicolumn{3}{|l|}{$\begin{array}{l}\text { The role of } \\
\text { different actors }\end{array}$} \\
\hline Government & $\begin{array}{l}\text { - } \text { providing subsidies } \\
\text { - setting platforms of interaction among } \\
\text { actors } \\
\text { - enforcing laws and regulations }\end{array}$ & - setting up farmers' markets \\
\hline $\begin{array}{l}\text { Farmers } \\
\text { Associations }\end{array}$ & $\begin{array}{l}\text { - developing technologies for making } \\
\text { local liquors } \\
\text { - production and sales of local liquors } \\
\text { - holding tourist events }\end{array}$ & - None \\
\hline Universities & - transferring knowledge & $\begin{array}{l}\text { - grants for study abroad programs } \\
\text { - active participation of faculty and students }\end{array}$ \\
\hline Local Farmers & - stable supplies of raw materials & $\begin{array}{l}\text { - tea-farming and -making } \\
\text { - tea cultural tour guides }\end{array}$ \\
\hline $\begin{array}{l}\text { Non-human } \\
\text { actors }\end{array}$ & $\begin{array}{l}\text { - local liquor-making traditions and } \\
\text { knowledge } \\
\text { - natural environment }\end{array}$ & $\begin{array}{l}\text { - local tea-making tradition } \\
\text { - natural environment }\end{array}$ \\
\hline
\end{tabular}




\section{Acknowledgement}

The first author would like to thank Ministry of Science and Technology in Taiwan for funding a part of this research (Grant No. 101-2410-H-002-189). The correspondent author would like to thank Ministry of Science and Technology in Taiwan for funding a part of this research (Grant No. 102-2410-H-002-158-NY2).

\section{References}

Chang, S. E. (2013). Blue Magpie TEAgriculture: Eco-tea cultivation and participatory farming in Pinglin Satoyama, Taiwan. Procedia - Social and Behavioral Sciences, 101, 14-22.

Murdoch, J. (1998), "The spaces of actor-network theory," Geoforum, 29 (4), 357-374.

Murdoch, J. (2000), "Networks: A new paradigm of rural development?," Journal of Rural Studies, 16 (4), 407-419.

Shucksmith, M. (2010), "Disintegrated rural development? Neo-endogenous rural development, planning and place-shaping in diffused power contexts," Sociologia Ruralis, 50 (1), 1-14.

Terluin, I. J. (2003), Differences in economic development in rural regions of advanced countries: An overview and critical analysis of theories, Journal of Rural Studies, 19 (3), 327-344.

Wang, W.-L. (2008), Results of promoting Taiwan's rural wineries and liquors, Agriculture policy and review, 192, 38-43. 